\title{
The Effect of Adopting Activity - Based Costing (ABC) on Maximizing Profitability in Jordanian Private Health Care Sector
}

\author{
Prof Suleiman Mustafa El-dalahmeh \\ Jerash University - Business college
}

Received: March 1, $2020 \quad$ Accepted: April 1, $2020 \quad$ Published: June 1, 2020

doi:10.5296/ajfa.v12i1.15958 URL: https://doi.org/10.5296/ajfa.v12i1.15958

\begin{abstract}
The aim of this study is to assess the effect of adopting activity - based costing (ABC) On maximizing profitability in Jordanian private health care sector. Stating the role of (ABC) system in maximizing profitability in Jordanian private hospitals, showing the availability of infrastructure and capabilities of needed to adopt and apply the (ABC) in Jordanian private hospitals To achieve the Study objectives, the researcher distributed (110) of the employees in Jordanian private hospitals, to identifying the obstacles that facing Jordanian private hospitals in adopting and applying ( $\mathrm{ABC}$ ) system. to achieve the study objectives, a questionnaire was designed and distributed to survey sample of 110 respondents who worked in Jordanian private hospitals as accountants, financial managers and internal editors. (90) questionnaires were returned and the response rate of which was (81.8\%). After using the statistical analysis program "Statistical package for social studies" (SPSS). The study concluded that adopting and applying $(\mathrm{ABC})$ system in Jordanian private hospitals play very important role in reducing cost in a way that maximizing profitability the results also, reveal that the infrastructure and capabilities needed to apply the (ABC) system are available in the Jordanian private hospitals in a medium degree. In addition, the results of the study showed there are a set of obstacles that facing the adoption and application (ABC) system in Jordanian private hospitals related to management, salaries and difficulty in allocating treatment costs to direct and indirect costs. The study recommended attracted qualified and trained persons who can apply (ABC) system and connivance the management of Jordanian private hospitals of the visibility of apply (ABC) system.
\end{abstract}

Keywords: Activity-based costing, Health care sector, Jordanian private hospitals, Indirect costs, Cost drivers, Maximizing profitability 


\section{Macrothink}

\section{Introduction}

The health services sector in the Hashemite kingdom of Jordan has witnessed rapid development over the past years, and increased the ability of Jordanian private hospitals, to compete in neighboring countries. the number of Jordanian private hospitals (70) hospitals, which is more the $60 \%$ of number of hospitals in Jordan, and employs more than 35000 employees, mostly, high income professionals, and the volume of investment in Jordanian private hospitals more than fourth billion dinars therefore, Jordanian private is one of the pillars of the Jordan economy.

Due to the lack of capacity to calculate the cost of heath services due to the multiplicity of health services the researcher believes that it is necessary to high light on Jordanian private hospitals to adopting the activity - based costing (ABC) because of accuracy (El-dalahmeh 2019).

\section{Problem of the study}

The problem of the study is represented in the following questions:

1- Dose the Activity - Based costing system enable Jordanian private hospitals to reduce health services costs in a way that maximizing profitability?

2- Do Jordanian private hospitals have infrastructure and capabilities needed to adopt and apply the activity- based costing system?

3- Are Jordanian private hospitals facing obstacles in adopting and applying the activity based costing system?

\section{Importance of the study}

This study derives its importance from the important of adopting and applying the activity based costing system in Jordanian private healthcare sector, which is the use of modern system in the allocation of treatment costs in Jordanian private hospitals. Activity based- costing system $(\mathrm{ABC})$ considering enormous technical development witnesses in the industrial sector in the world in general. This system has proven its ability to reduce indirect industrial costs in the industrial sector and to its accuracy of information, which helps management to make rational decisions in pricing services and this is what prompted the researcher to conduct this study in Jordanian private healthcare sector.

\section{Objectives of the study}

The main objectives of the study are represented in the following:

1- Stating the role of activity - based costing system in maximizing profitability in Jordanian private hospitals.

2- Showing the availability of infrastructure and capabilities needed to adopt and apply the activity - based costing system in Jordanian private hospitals. 
3- Identifying the obstacles that facing Jordanian private hospitals in adopting and applying activity - based costing.

\section{Hypotheses of the study}

Based on the question of the study's problem the following hypotheses are formulated:

HO1: The application of ABC system does not enable private hospitals in Jordan to reduce the cost of health services in away that maximizes profitability.

HO2: The infrastructure and capability needed to apply the activity - based costing system are not available in the Jordanian private hospitals.

HO3: There are no obstacle that facing the Jordanian private hospitals in the applying of activity based costing system.

\section{Theoretical framework}

A cost - based system of activities emerged in 1949 when (Goetz) defended the principle of the system, and pointed out, that each indirect cost complex should be homogeneous and that each complex could change with the change of certain process, indicating the casual relation ship between cost complex and activities (Dury, 2002). In the late $1985_{\mathrm{s}}$ and early $1990_{\mathrm{s}}$, the activity - based costing system (ABC) attracted the attention of researcher and academics due to overcoming the problems arising from the use of traditional costing systems. The (ABC) was implemented in a large number of factories and companies, and the system of (ABC) proved its ability to reduce costs (Cooper \& Kaplan 1991, pp 130 -135). Activity - based Costing system (ABC) was defined by (Horngren,et al 2005) as the system which works on assembling the manufacturing overhead costs for each drivers on products (Horngren 2005: 131 ). also, defined by (El-dalahmeh, 2019) Activity - based system costing as managerial accounting method that allocate indirect overhead costs to activities and the assigns them to objects.

\section{Benefits of activity - based system (ABC)}

1- In planning: Activity - based costing system benefit the administration in the planning, where activity - based system enables the study of each activity performed by the enterprise independently and bread winner can divide activity into A- Activity add value to the product and these kind of activities must be taken care of and developed.

B -Activities do not add value to the product, and this disposed of or reduced to a minimum.

2- In controlling: Activity - based costing system play an active role in controlling cost elements, where the practice control, over the level of activities rather than the final product level, as in traditional cost system, enabling to measure cost of production and analyze profitability.

3- In decision making: Activity - based costing system assist administration in making pricing decisions because company will be in a competitive position, because the costs of its product and services are precisely defined. 


\section{Criticism of Activity - based costing system:}

1- Activity - based costing system is a process of loading traditional costing systems that rely on loading and allocating indirect industrial costs on a cause - and - effect relationship with more details in the activity code.

2- The efficiency of using (ABC) depends on the proper selection of cost drivers, and this is not easy, and it is necessary to determine the best cost drivers of the activity and study the behavior effects.

3- The application of $(\mathrm{ABC})$ requires high costs and considerable effort, so some services organizations are reluctant to use it.

\section{Literature review}

- Al Hanini (2018) Study the impact of adopting activity - based costing (ABC) on decreasing cost and maximizing profitability in industrial companies listed in Amman stock exchange. The study revealed that adopting and implementing (ABC) play a good role in reducing costs and maximizing profitability. The results also reveal that some it industrial companies have the infrastructure to adopt and implement the (ABC) system to a medium degree, while other companies lack any of these components.

- Al-Bader (2017). Attempted to clarify the impact of applying activity - based costing system in confectionary companies. the study concluded that the most cost effective systems to enhance profitability were the $(\mathrm{ABC})$.

- $\quad$ Yousef, Z, \& Odeh (2014) study " The importance of the system of activity based costing $(A B C)$ in the decision making ". Their study demonstrated that the application of (ABC) helps gather the manufacturing overhead costs of the enterprise at cost points to be distributed later on good and services.

- Bin Moussa's (2013) study " the impact of activity - based costing on decreasing cost and enhancing the performance " aimed at identifying the role of the (ABC) system in cost management, its applicability of required data due to the short coming of traditional systems the study demonstrated that the use of the (ABC) system leads to more accurate calculation of the cost of treatment services.

- Krishan (2006) study the application (ABC) system at higher learning institution. The study concluded the $(\mathrm{ABC})$ system establishes accurate basis for determining the real cost of the student and not necessary for (ABC) system implementation, provides cost accounting staff to determine which activities do not add value, and thus exclude them without affecting the final output.

- Martin, Melissa (2005) conducted a study entitled the association between (ABC) system adoption and the performance of hospitals. The study revealed that the benefit of applying the (ABC) system differ from one hospital to another. In profit oriented hospitals, the applying of (ABC) system increased profitability, helped increase occupancy rate and thus was increased 
by the hospital patients, as the (ABC) system contributed to increased control over operational costs and there was no impact on increasing profitability in non- profit hospitals.

- Grandlich, Chery,(2004) Study the use of cost accounting activities in surgical operations conducted this study in a hospital in Milwaukee in the United States of America The researcher has found that the application of a cost system based on activities in health hospitals works on 1 - enable hospitals to determine their costs accurately 2- Empowerment Hospitals can develop appropriate pricing mechanisms for their service to patients. 3. Give detailed information about the costs of activities within the hospital, which enables them to compare the results of work with competitors.

- Ittner \& et al (2002) the study was conducted in united states of America and aimed to examining the extent of association between the activity based-costing and the manufacturing performance. The study found that the reason for wide spread of. (ABC) system mandated to the basis of activities, was due to high quality levels, and decrease in industrial costs, as the study found that the use of $(\mathrm{ABC})$ system is not related to return on investment.

- $\quad$ Cooper \& Kaplan (1998) study entitled " Cost -cutting activity ". This study aimed to find out whether the application of the (ABC) system will head to a reduction in costs. The study concluded that the application of (ABC) system will reduce costs by excluding activities that do not add value to the product unit, and retaining the activities that add value to the product unit, and retaining the activities that add value to the product. This leads decrease costs.

\section{Research Methodology}

Data collection sources were both primary and secondary. The primary sources represent the questionnaire tool that was designed according to Likert scale, from 1-5. While the secondary resources of the study data constituted books, periodicals related to the subject of the study.

Population of the study: population of the study consists of (70) Jordanian private hospitals (www.phajordan.org)

Sample of the study: the study was conducted on a random sample of (110) employees in the field of accounting and financial managers, accountants, internal (Auditor), (90) questionnaires were returned and the response rate of which was $(81.8 \%)$ of the population.

Statistical analysis of data: In order to analysis the data, the researcher used the statistical package for social studies (SPSS):

- Reliability: The Alpha - Cronbach was used to measure the internal stability of the resolution paragraphs and internal consistency between respondent answers. The Coefficient of stability ( $\alpha=72.8 \%$ ) which is excellent compared to the acceptable rate of $60 \%$.

- The normal distribution Test. (Kolmogorov - Smirnov). The research conducting the Statistical analysis shows that the data were distributed naturally. The mean ( $Z$ ) for the three hypotheses of the study was grater than ( 0.05$)$. as shown in Table 1. 
One - Sample Kolmogorov - Smirnov Test

\begin{tabular}{|l|l|l|l|}
\hline Hypotheses & H1 & H2 & H3 \\
\hline Kolmogorov - Smirnov Z & 1.052 & 1.352 & 1.578 \\
\hline
\end{tabular}

Hypotheses testing: The hypotheses of the study were tested as follows:

1- One sample $\mathrm{T}$ - test at significant level of 5\% according to the role of decision which provides for acceptance of the hypothesis if the calculated $\mathrm{T}$ is less than $\mathrm{T}$ tabular, and reject it if it is greater.

2- Descriptive analysis: which includes frequencies, the mean and standard deviation to accept or reject the hypothesis paragraph.

Table 2. Arithmetic averages and standard deviations of the role of $\mathrm{ABC}$ cost system in maximizing profitability. Jordanian hospitals from the point of view of the study sample

\begin{tabular}{|c|c|c|c|c|c|}
\hline No & Items & Mean & S.T & Percentage $\%$ & $\begin{array}{l}\text { Level of } \\
\text { importance }\end{array}$ \\
\hline 1 & $\begin{array}{l}\text { The application of }(\mathrm{ABC}) \text { system reduces the } \\
\text { time and effort required to carry out the } \\
\text { activities and thus reduce cost. }\end{array}$ & 4.68 & 0.56 & $93.6 \%$ & Very High \\
\hline 2 & $\begin{array}{l}\text { ABC system helps control and reduce early or } \\
\text { reduce costs }\end{array}$ & 4.25 & 0.62 & $85 \%$ & Very High \\
\hline 3 & $\begin{array}{l}\text { The Jordanian health services sector is } \\
\text { witnessing intense competition among private } \\
\text { hospitals }\end{array}$ & 4.20 & 0.70 & $84 \%$ & Very High \\
\hline 4 & $\begin{array}{l}\text { ABC system helps in determining the prices of } \\
\text { health service better and more accurately }\end{array}$ & 4.18 & 0.76 & $83.6 \%$ & Very high \\
\hline 5 & $\begin{array}{l}\text { The indirect costs of health services are an } \\
\text { important of the cost of health services } \\
\text { provided to the patient }\end{array}$ & 4.02 & 0.85 & $80.4 \%$ & Very High \\
\hline 6 & $\begin{array}{l}\text { Guided by the casual relationship between the } \\
\text { indirect costs of health services and the } \\
\text { activities that caused the leads to the excluding } \\
\text { activities that do not add value or benefit to the } \\
\text { patient. }\end{array}$ & 3.88 & 1.12 & $77.6 \%$ & High \\
\hline 7 & $\begin{array}{l}\text { The role of } \mathrm{ABC} \text { system in maximizing } \\
\text { profitability }\end{array}$ & 4.21 & 0.38 & $84.2 \%$ & Very High \\
\hline & Total Average & 4.20 & 0.79 & $84 . \%$ & Very High \\
\hline
\end{tabular}


Table 3. Hypothesis (1) Testing Result

\begin{tabular}{|l|l|l|l|l|l|l|}
\hline $\begin{array}{l}\text { Calculated } \\
\mathrm{T}\end{array}$ & T tabular & SIG & $\begin{array}{l}\text { Allowed } \\
\text { error }\end{array}$ & Result & Mean & S.D \\
\hline 2.199 & 1.645 & 0.32 & 0.05 & Rejected & 4.20 & 0.79 \\
\hline
\end{tabular}

Table 3 shows that the calculated $\mathrm{T}$ is greater than $\mathrm{T}$. tabular and this means that the application of $\mathrm{ABC}$ system enables private hospitals in Jordan to reduce the costs of health services in away that maximizing profitability. Therefore, the researcher rejects the null hypothesis and accept the alternative hypothesis according to the role of decision arithmetic averages and standard s deviation to provide the $\mathrm{ABC}$ system possibilities in measuring the cost of health services.

Table 4. The availability of infrastructure and capabilities needed to adopt and apply (ABC) system in Jordanian hospitals

\begin{tabular}{|c|c|c|c|c|c|}
\hline No & Items & Mean & S.T & Percentage $\%$ & $\begin{array}{l}\text { Level of } \\
\text { importance }\end{array}$ \\
\hline 1 & $\begin{array}{l}\text { The corresponding work mechanism in } \\
\text { the Jordanian private hospitals is } \\
\text { imposed by the administration, but it } \\
\text { is possible to develop method to } \\
\text { calculate the cost of health service } \\
\text { accurately }\end{array}$ & 3.46 & 0.63 & $69.2 \%$ & Medium \\
\hline 2 & $\begin{array}{l}\text { Determine the price of health service } \\
\text { provided to patients by adding a margin } \\
\text { (Markup) to the cost of service provided } \\
\text { to patient }\end{array}$ & 3.44 & 0.78 & $68.8 \%$ & Medium \\
\hline 3 & $\begin{array}{l}\text { The Jordanian private hospitals have a } \\
\text { department specialized in determining } \\
\text { the cost of health services that provided } \\
\text { to patient }\end{array}$ & 3.31 & 0.67 & $66.2 \%$ & Medium \\
\hline 4 & $\begin{array}{l}\text { The health services provided to patients } \\
\text { in private Jordanian hospitals to re - } \\
\text { engineering from time to time in order } \\
\text { to get rid of services that do not benefit } \\
\text { patients. }\end{array}$ & 3.60 & 6.70 & $67 \%$ & Medium \\
\hline 5 & $\begin{array}{l}\text { The extent to which infrastructure and } \\
\text { the potential to adopt and apply the } \\
\text { ABC system the Jordanian private } \\
\text { hospitals are available }\end{array}$ & 3.25 & 0.58 & $65 \%$ & Medium \\
\hline & Total Average & 3.412 & 0.59 & $62 \%$ & Medium \\
\hline
\end{tabular}


Table 5. Hypothesis 2 result

\begin{tabular}{|l|l|l|l|l|l|l|}
\hline $\begin{array}{l}\text { Calculated } \\
\mathrm{T}\end{array}$ & T tabular & SIG & $\begin{array}{l}\text { Allowed } \\
\text { error }\end{array}$ & Result & Mean & S.D \\
\hline 2.032 & 1.645 & 0.042 & 0.05 & Rejected & 3.412 & 0.59 \\
\hline
\end{tabular}

Table 5 shows that calculated $(\mathrm{T})$ is greater than ( $\mathrm{T}$, tabular). Therefore, the researcher rejects the null hypothesis according to the role of the decision and accept the alternative hypothesis: - The infrastructure and capabilities needed to apply the (ABC) system are available in the Jordanian private hospitals.

Table 6. Arithmetic averages and standard deviations to the obstacles of applying ABC system in Jordanian private hospitals

\begin{tabular}{|c|c|c|c|c|c|}
\hline No & Items & Mean & S.T & Percentage \% & $\begin{array}{l}\text { Level of } \\
\text { importance }\end{array}$ \\
\hline 1 & $\begin{array}{l}\text { The hospital administration is not } \\
\text { convinced of the feasibility of } \mathrm{ABC} \\
\text { system in Jordanian private hospitals. }\end{array}$ & 4.05 & 1.26 & $81 \%$ & Very High \\
\hline 2 & $\begin{array}{l}\text { The average level of salaries of financial } \\
\text { state prevents } \mathrm{ABC} \text { system from being } \\
\text { applied due to the time and investment it } \\
\text { needs }\end{array}$ & 3.66 & 0.91 & $73.2 \%$ & High \\
\hline 3 & $\begin{array}{l}\text { The application of } \mathrm{ABC} \text { system in } \\
\text { Jordanian private hospitals costly, and } \\
\text { less effective than the cost of its } \\
\text { implementation }\end{array}$ & 3.76 & 0.95 & $75.2 \%$ & High \\
\hline 4 & $\begin{array}{l}\text { Cost management personal are not } \\
\text { eligible to apply (ABC) system in } \\
\text { Jordanian private hospitals }\end{array}$ & 3.82 & 1.04 & $76.4 \%$ & High \\
\hline 5 & $\begin{array}{l}\text { The cost centers in Jordanian private } \\
\text { hospitals are not defined by the } \\
\text { appropriate application for } \mathrm{ABC} \text { system }\end{array}$ & 3.44 & 1.15 & $68.8 \%$ & Moderate \\
\hline 6 & $\begin{array}{l}\text { The difficulty of dividing the cost of the } \\
\text { patients health services directly and } \\
\text { indirectly }\end{array}$ & 2.56 & 1.10 & $51.2 \%$ & Little \\
\hline 7 & $\begin{array}{l}\text { The pricing of health services in } \\
\text { Jordanian private hospitals depends } \\
\text { more on supply and demand factors and } \\
\text { competition on the cost of service. }\end{array}$ & 3.77 & 1.06 & $75.4 \%$ & High \\
\hline & Total average & 3.58 & 0.65 & $71.6 \%$ & High \\
\hline
\end{tabular}

From the table 6 above the overall average of all paragraphs is ( 3.58 ) and is greater than the average of the study tool ( 3 ), it is also, noted from table 6 that there are is agreement in the sample of the study on the obstacle of applying ( $A B C$ ) system in Jordanian private hospitals. 
Based on this, the null hypothesis was rejected and accepts the alternative hypothesis.

Table 7. Hypothesis 3 result

\begin{tabular}{|l|l|l|l|l|l|l|}
\hline $\begin{array}{l}\text { Calculated } \\
\mathrm{T}\end{array}$ & T tabular & SIG & $\begin{array}{l}\text { Allowed } \\
\text { error }\end{array}$ & Result & Mean & S.D \\
\hline 2.664 & 1.645 & 0.004 & 0.05 & Rejected & 3.58 & 0.65 \\
\hline
\end{tabular}

Therefore, it rejects the third null hypothesis and accepts the alternative hypothesis that there are obstacles to the application of (ABC) system in Jordanian private hospitals.

\section{Results and discussion}

The study results indicate that the adoption of activity - based costing system in Jordanian private healthcare contributes to reducing costs by concentrating on value added activities and excluding activities that have no added value. (ABC) system also reduces the costs because its assists in reducing time and efforts. Therefore, it helps increase profitability through the system. The adopting and applying activity based - cost in Jordanian private hospitals leads to improve the performance of staff and efficiency of hospital services. Also the efficiency of administration in planning and assist the administration in making pricing decisions, which leads to achieve a competitive position because the costs of its services are precisely defined. The results of statistical analysis of data indicates that the role of $(\mathrm{ABC})$ system in maximizing profitability in Jordanian private hospitals is very high. In general, there is agreement in the opinions of the study sample on importance of the role of (ABC) system in maximizing profitability, where the total average of all paragraphs in table (2) (4.20), standard deviation (0.79) and the level of importance very high, percentage ( $84 \%$ ) also, the infrastructure and capabilities needed for the adopting and applying the (ABC) system in Jordanian private hospitals are available to a medium extent. Finally, the results of the statistical analysis showed that there are obstacles facing the applying of activity - based costing system in Jordanian private hospitals related to management, salaries and difficulty allocating treatment cost to direct and indirect cost.

\section{Recommendations}

In the light of the findings, the researcher recommends the following:

1- Attract qualified and trained persons who can apply activities - based costing.

2- Connivance the management of Jordanian private hospitals of the feasibility of applying activity base-costing system.

3- Conducting other studies on the services sector in particular due to the high percentage of indirect costs.

\section{References}

Al- bader. (2017). the impact of activity based - costing in enhancing the profitability of Jordanian food manufacturing companies. Unpublished master thesis, middle east university, Amman, Jordan. 


\section{Macrothink}

Asian Journal of Finance \& Accounting

ISSN 1946-052X 2020, Vol. 12, No. 1

Al- Hanini Eman. (2018). The impact of adopting activity based costing (ABC) on decreasing cost and maximizing profitability in industrial companies listed. Amman stock Exchange. Academy of accounting and financial studies journal, 22(5), 1-8.

Bin mousa, I.A.D (2013). The impact of activity based costing on decreasing cost and enhancing the performance. Unpublished master thesis, Liaside university. Algeria.

Cooper Robin, Kaplan. S. Robert. (1991). The design of cost management system: Text and reading, New jersey, prentice, tt all, 130-135.

Cooper, \& Kaplan, R. (1998). Cost cutting activity economist, 348, 57-67.

Dargham, MM (2007) The availability of the main fundamentals to implementing ABC on industrial companies in GAZA, Islamic university for Humanities, 15(2), 679 -725.

Dury, Colin. (2002). Management and cost accounting, $5^{\text {th }}$ ed, Thomson Learning, 340.

EL-dalahmeh suleiman. (2019). Managerial accounting and edition. Alwarag - pub, Amman - Jordan pp (261-280).

Graudich, Chery. (2004). using activity - based accounting in surger: AORN journal, 9(1), 189192. https://doi.org/10.1016/S0001-2092(06)61152-6

Horengren, C, T, Sundem, G. L., \& Stration, W. O. (2005). Introduction management accounting, (Thirteenth edition). Wpper saddle River-New jersey, prentice-Hall.

Horngren, C.T, sundew, G 1. \& Stratton, W. O. (2005). Introduction to management accounting. (Thirteenth, Edition) Upper saddle river, New jersey, prentice Hall.

https://Moh.Gov.jo

https://SSRN.com

https://www.phajordan.org

Ittner, G, Lanen, W, \& Larcker, D. (2002). The association between Activity - based costing and manufacturing performance. Journal of accounting research, 40(3), June, 111-130. https://doi.org/10.1111/1475-679X.00068

Krishnan, \& balagan (2006). An application of (ABC) system in higher learning institution: A local case study. Contemporary Management research, 2(2), 75-90. https://doi.org/10.7903/cmr.652

Martin, Melissa. (2005). The association between (ABC) system adoption and hospital performance "PhD". Candidate unpublished university of southern California 3660 Troas dale park wag, los angels CA 90089 - 0441.USA.

Private hospital, Association. (2019). Kingdom of Jordan. 